\title{
The goal of the methodology for legal regulation of victim protection
}

\author{
Oleg Aleksandrovich Tarnavsky ${ }^{1}$ \\ LLC Gazprom Energo, Deputy General Director, Moscow, Russia
}

\begin{abstract}
The purpose of the research is to develop a theoretical concept of a security and recovery arrangements for protecting the violated rights and interests of persons, who have suffered from the commission of crimes in the framework of criminal proceedings, with the determination of the development prospects, legal support as well as the use in law enforcement practice. The methodological background of this research was such fundamental methods of scientific knowledge as general methods (analysis, synthesis, induction, deduction, analogy), as well as special methods (comparative legal and formal legal). The research resulted in making the conclusion about the positive transformations in the criminal process of recent years; finally, the victim of a crime is gradually becoming key in the context of the changes introduced by the criminal procedural legislation. But it is believed by the author that the improvement of the criminal procedural mechanism should be not occasional but a comprehensive reform of the goals, objectives and principles of all criminal procedural activities, with an emphasis on the compensatory mechanism of legal regulation. The novelty of the research lies in the author's approach to the consideration of the stated problem and that it made it possible to assert that the scientific understanding of the ideological content of the methodology of legal regulation of the protection of a victim implies the reform of criminal proceedings, from its content to the procedural position of the victim and restorative procedures.
\end{abstract}

Keywords: criminal procedure, criminal process, victim.

\section{Introduction}

The lack of an effective victim protection mechanism in Russia has been a concern for a long time. To assess the depth of the problem, the calculated data can be considered. Based on information from the Prosecutor General's Office of the Russian Federation [1], it is possible to conclude that out of the registered crimes (slightly more than 2 million), every second (1031987) has been investigated, and only $2 / 5$ of the registered crimes (about $700,000)$ are handed over to court with a letter of accusation, a charge sheet, an indictment. Of these, $3 / 10(579,000)$ shares of the registered ones are considered on the merits in the court of first instance and 1/10 part (115,000 final judgements) are approved in legal force.

\footnotetext{
${ }^{1}$ Corresponding author: iens.orenburg@gmail.com
} 
Thus, only in every tenth case, the victim has the right to expect that its rights and legitimate interests will be protected by criminal jurisdiction. Meanwhile, as noted in the annual reports of the Commissioner for Human Rights in the Russian Federation [2], the number of victims of crime is growing by $3 \%$ annually. At the same time, the number of complaints about the lack of registration of statements of crime by law enforcement agencies increased by $29 \%$, and about refusals to initiate a criminal case - by $27 \%$. Such statistics indicate the limited access of victims to justice, systematic infractions and repeated violations of Art. 52 of the Constitution of the Russian Federation.

Another important aspect in assessing the level of effectiveness of the existing methodological mechanism of legal regulation of the considered category of parties to the criminal process is the compensation to the victims of the harm caused by the crime. In accordance with the provisions of the existing legislation, both pecuniary and non-pecuniary damages stated in a civil claim are subject to compensation. In this regard, the Federal Bailiff Service on their departmental website [3] shows the following picture: in $2019,449,996,612$ roubles were subject to collection, and 70,114,646 roubles were actually collected, which is about $15 \%$; in $2020,626,930,563$ roubles were subject to collection, and $71,585,187$ roubles were actually recovered, which made up $11.4 \%$. Taking into account the fact that about $1,617,177$ people are recognised as victims annually, the average share of recovery for each victim in compensation for damage caused by a crime is 44 roubles 26 kopecks, while keeping one convicted person in places of deprivation of liberty per month is 4,800 roubles from the budgetary funds generated at the expense of conscientious taxpayers, which means the victims of crimes themselves.

In such an absurd situation, there is no need to talk about any proven problems within the framework of the stated topic. Therefore, the real urgent task of the science of criminal procedure is to study the existing methodology of legal regulation for its effectiveness and actualisation.

The research objectives are of both intermediate and forward-looking nature. The immediate goal is to determine the vector of improving the methodology of legal regulation of compensation for harm caused by a crime. Here it is believed that it is asocial to discuss the possibilities of the methodology outside the legal environment. Any final concept in the field of criminal jurisdiction should be embodied in a regulatory form, binding and mandatory. The ultimate goal is to develop a theoretical concept of a security and restorative mechanism for protecting the violated rights and interests of persons who have suffered from the commission of crimes in the framework of criminal proceedings, with the determination of the prospects for its development, legal support, and also use in law enforcement practices.

Any methodological research into public relations is based on both law-making and law enforcement aspects. Meanwhile, this is the main but not exclusive understanding of this legal phenomenon, since it is being transformed according to the nature of the regulated relationships. In the criminal process, the legal regulation methodology is determined by the appointment of state bodies and officials designed to protect persons, who have suffered from crimes and persons, from any illegal and unjustified criminal prosecution. However, as the long-term practice of implementing the current mechanism of legal regulation of the criminal procedural relations through the institution of compensation for harm to victims shows, the level of protection of the above-mentioned persons remains low. The author sees the origins of this problem in the absence of a unified theoretical model and the quality of the legislative techniques.

\section{$2 \quad$ Methods}


The methodological basis for this research was the fundamental methods of scientific knowledge as follows: general methods (analysis, synthesis, induction, deduction, analogy), as well as special methods (comparative legal and formal legal). The use of those methods made it possible to deeply analyse the criminal procedural legislation, identify its problems and determine ways for solving them.

\section{$3 \quad$ Research results}

The conducted scholarly reflection of the message of the methodology of legal regulation of the protection of a victim presupposes the reform of criminal proceedings, starting with their content, the procedural position of a victim and recovery procedures.

A person should be recognised as a victim not only at the time of the issuance of the related judgement, and at the same time with the initiation of a criminal case, but possibly earlier, from the onset of criminal prosecution, at the stage of filing an application or reporting a crime. A person, who filed a statement about the violation of his/her rights and interests, a committed crime (or about the threat of such a violation), with a demand for restoration of them, along with the acceptance of the statement, must be officially recognised as an aggrieved person or a victim of a crime. Such a person should be explained verbally and served with a notice of his/her three potentially possible legal positions in the framework of a future criminal case, such as an aggrieved person, civil claimant, private prosecutor. Taken together, they all together create a model for the participation of victims of a crime in criminal proceedings.

Recovery of damage caused as a result of a committed crime on the basis of its non-belonging to the provisions of a civil claim and in view of its unsettledness by its criminal procedural legislation in full, should become a separate criminal procedural institution.

At the same time, it should be noted that outside the framework of the process (in the sense of the lack of regulation by the provisions of the criminal procedure law) such procedures as the principled negotiations, mediation, facilitation and reconciliation should continue to remain.

\section{Discussion}

It should be noted with regret that the current methodology of legal regulation of criminal procedural legal relations is focused on the departmental interest in making procedural decisions in conditions of obviousness and guarantee of their viability, that is, without subsequent cancellation. This is evidenced by both the afore-mentioned practice and legislative structure of the Criminal Procedure Code of the Russian Federation with its significant transfer of procedural tools to the stage of initiating a criminal case (from the expansion of verification actions and duration extension under Article 144 of the Criminal Procedure Code of the Russian Federation to the appearance of new parties to the criminal process with an unregulated status (Art. 56.1 of the Code of Criminal Procedure of the Russian Federation or the proposed project novel about the conciliator of Art.58.1 of the draft law on amendments [4]); heap of departmental duplicated forms of control and supervision by the prosecutor, the head of the inquiry unit, the head of the inquiry body; simplification and reduction of judicial procedures, up to "postal justice" [5], which sometimes makes it impossible to restore social justice not only to the accused but also to the victim; by a huge number of higher forms of appeal against court rulings and grounds for appeal in the first instance as incapable of making lawful and well-founded final 
decisions. The above means pressure points of the subject area of the doctrine of criminal procedure law for a long period of time. In this regard, one should agree with civilians that "any fruitful, effective research should begin with the establishment of methodological principles and framework of work" [6, p. 14].

Currently, there is a certain spread of the comparative research method that is focused on studying foreign legislation, law and practice of its application [5, p. 19]; digitalisation method [7] of criminal procedure and self-reflection [8]; the method of historical knowledge [9], syntagmatics and paradigmatics [10]. It should be noted that the penetration of methods from related (non-legal) sciences into the science of criminal procedure, such as sociology, mathematics and economics has become an upcoming trend. The latter is especially important for the creation of legal structures for assessing and the effectiveness of financial costs in compensation for harm caused to victims of crime. It is necessary and important to verify these methods, but it is a part of a single anchor mechanism, which, without the main mainspring, cannot convert energy into impulses and maintain a balance of oscillations, and therefore rotate the gear mechanism of criminal proceedings. This key "spring" should be the character of the victim.

One of the key aspects to which the authors of various concepts of criminal policy, reforming criminal procedural institutions attach special priority is the fundamental (basic) provisions. In this regard, the developments of Endoltseva, Endoltseva, Platonova should be highlighted [11]. They propose a system of principles based on a socially oriented approach, the content of which includes social conditioning, democratic essence and legitimacy, scientific validity and expediency, poly-normativity and the rule of law, complexity and integrity, humanity and morality, preventive impact on crime, legality and justice etc. [11, p. 644].

Other authors also take the institution of principles of criminal proceedings as the basis for the methodology of legal regulation. In this regard, it is noted that the procedure for criminal proceedings is interdependent on the specified requirements within the system of principles, their difference for criminal process and criminal procedure law, criminal procedure [12, p. 14], oversaturation with the principles of the existing Criminal Procedure Code of the Russian Federation and the need to minimise them, focus on justice and morality as formational markers [13] or, conversely, the inclusion of additional principles as legal guarantees, the expansion of the system of principles $[14,15]$ or the division of the system of principles according to the stages of production according to criminal case and lack of commonality of goals and objectives [16]. The need to improve the procedural form is singled out as the fundamental tool of the methodological approach to reforming the criminal process: from its simplification (but not simplification) [10, p. 14], to differentiation and unification [17]. Less often, authors put emphasis in their research on the goals and objectives of criminal justice. In the context of the research conducted, noted can be the position on the existence of social goals of criminal procedural activity, ensuring the safety of the public environment through the application of criminal law, the performance of public functions, protection from criminal encroachments and a fair resolution of a criminal law dispute [18], as well as idea of the purpose of criminal procedure law (criminal procedure) as a tool to ensure stability in society $[19, \mathrm{p} .44]$.

Among all the theoretical approaches in the formulation of concepts for restoring the interests of victims in the criminal process, which we studied $[20$, p. $12 ; 21$, p. $24 ; 22$, pp. $76,83]$, the key aspect should be the obligations of the state to the individual including outside the framework of criminal procedure procedures and along with them.

In this regard, according to Lukyantsev, "the Russian legal system is faced with the challenge of introducing into Russian law enforcement practice such alternative methods as 
mediation, reconciliation, negotiations, preliminary assessment of a neutral party, a settlement agreement, which are successfully applied in the legal environment of foreign countries" [23].

A comparative legal analysis indicates the presence of restorative (compensatory) mechanisms in foreign countries, which should be noted by the Russian legislator.

\section{Conclusion}

Violation by a crime of legal rights, freedoms and interests of an individual, as well as the rights and interests of a legal entity as a victim, entails the fulfilment by the state of the obligation to the aggrieved persons to carry out legal restoration activities. In our opinion, it is this that is the main "spring" of the criminal procedural activities. Criminal proceedings should be viewed as an effective security mechanism to restore persons' rights and interests violated by a crime.

Therefore, the improvement of the criminal procedural methodology should be aimed at reforming the goals, objectives and principles of the criminal procedural legislation and the practice of its application, with an emphasis on compensation for harm and restoration of social justice.

\section{References}

1. The State of Crime in Russia in January-December 2020, Official website of the General Prosecutor's Office of the Russian Federation: Legal Statistics Section (2020). Accessed on: February 21, 2021. [Online]. Available: http://crimestat.ru/analytics

2. Report of the Commissioner for Human Rights in the Russian Federation for 2019, Official website of the Commissioner for Human Rights in the Russian Federation. Accessed on: February 21, 2021. [Online]. Available: https://ombudsmanrf.org/upload/files/docs/lib/doc2019_fin_compressed.pdf

3. Departmental statistical reporting in 2019, 2020, Official website of the Federal Bailiff Service. Accessed on: February 21, 2021. [Online]. Available: https://fssp.gov.ru/statistics/

4. Draft Federal Law “Amendments to the Criminal Procedure Code of the Russian Federation in Connection with the Implementation of the Concept for the Development of a Network of Mediation Services until 2017 in order to implement restorative justice in relation to children, including those who have committed socially dangerous acts but have not reached the age of which comes criminal responsibility in the Russian Federation", prepared by the Russian Ministry of Justice on 07 August 2017, Garant legal reference system. Accessed on: February 26, 2021. [Online]. Available: http://base.garant.ru/56723611

5. A.A. Trefilov, Strafprozessuale vergleichende Rechtswissenschaft (NIPKC-Voskhod-A, Moscow, 2018)

6. A. Gabov, V.G. Golubtsov, O.A. Kuznetsova, Methodological Problems of Civil Studies: Collection of Articles, Yearbook, 2 (2017)

7. T.Y. Vilkova, L.N. Maslennikova, Perm University Herald. Juridical Sciences, 46, 728-751 (2019). https://doi: 10.17072/1995-4190-2019-46-728-751

8. O.A. Zaytsev, P.S. Pastukhov, Perm University Herald. Juridical Sciences, 46, 752-777 (2019). https://doi: 10.17072/1995-4190-2019-46-752-777 
9. T.K. Ryabinina, Russian Journal of Criminology, 14(3), 512-526 (2020). https://doi: $10.17150 / 2500-4255.2020$

10. V.A. Azarov, A.V. Boyarskaya, Tomsk State University Journal of Law, 37, 5-20 (2020). https://doi: 10.17223/22253513/37/1

11. A.V. Endoltseva, Yu.V. Endoltseva, N.I. Platonova, Russian Journal of Criminology, 13(4), 641-650 (2019). https://doi: 10.17150/2500-4255.2019.13(4).641-650

12. S.S. Bezrukov, Principy ugolovnogo processa [Principles of Criminal Procedure], Abstract of a Doctor of Law (Moscow, 2016)

13. N.S. Manova, M.A. Baranova, Perm University Herald. Juridical Sciences, 45, 567-570 (2019). https://doi: 10.17072/1995-4190-2019-45-564-593

14. T.Yu. Vilkova, S.A. Nasonov, The Principle of Citizens' Engagement in the Administration of Justice in Criminal Proceedings (Izdatelsvo YUrait, Moscow, 2020)

15. A.V. Guskova, Institute for the Resumption of Criminal Proceedings in View of New or Newly Discovered Circumstances as an Embodiment of the Principles of Criminal Proceedings and as a Deviation from Them, in Almanac No. 1: Debatable aspects of the development and application of criminal procedure legislation, collection of articles, 52-63 (Kazan, 2018)

16. I.A. Popov, On some Principles of the Russian Criminal Process during the Preliminary Investigation and in the Trial, in Problems of Preliminary Investigation and Interrogation: Collection of Research Articles and Papers, 80-83 (Moscow, 2019)

17. E.V. Mishchenko, Problemy differenciacii i unifikacii ugolovno-processualnyh form proizvodstv po otdelnym kategoriyam ugolovnyh del [Problems of Differentiation and Unification of the Criminal Procedural Forms of Proceedings by Category of Criminal Case], Abstract of a Doctor of Law (Moscow, 2014)

18. G.N. Vetrova, On the Relationship between Goals and Means of Achieving them in Criminal Proceedings, in Legal Problems of Strengthening Russian Statehood: Collection of Articles, 14-21 (Tomsk, 2019)

19. A.B. Divaev, The Concept and Content of the Goal of Criminal Procedure (Criminal Procedure Law), in Legal Problems of Strengthening Russian Statehood: Collection of Articles, 36-44 (Tomsk, 2019)

20. V.N. Grigoriev, Criminological Journal, 2(10), 12-15 (2006)

21. S.M. Darovskikh, Sudebnye pravovye pozicii v ugolovnom sudoproizvodstve: teoreticheskie osnovy i processualnye formy [Judicial Legal Positions in Criminal Proceedings: Theoretical Foundations and Procedural Forms], Abstract of a Doctor Thesis (Moscow, 2011)

22. O.A. Zaitsev, State Protection of Parties to Criminal Proceedings (Examen Publishing House, Moscow, 2002)

23. A. Lucyantsev, Terra Economicus, 13(3) 147-155 (2015) 